\title{
Influence of Citizens and Form of Government on Alternative Service Delivery Choices in Local Governments
}

\author{
Azhar Manzoor ${ }^{1}$ \\ ${ }^{1}$ University of Central Punjab, Lahore, Pakistan \\ Correspondence: Azhar Manzoor, University of Central Punjab, Lahore, Pakistan. E-mail: \\ azhar.manzoor@ucp.edu.pk
}

Received: August 10, 2016

Accepted: October 20, 2016 Online Published: October 30, 2016

doi:10.5539/par.v5n2p19

URL: http://dx.doi.org/10.5539/par.v5n2p19

\begin{abstract}
Citizens are an essential part of democratic setup and especially as recipients of public services play a crucial role in decisions regarding provision of these services. Citizen engagement not only provides feedback on the activities undertaken by government but may also influence how governments plans for future allocation of resources and means for providing various services. Citizen engagement emerges from the initiatives taken by the governments to improve the quality of government planning, processes, and decisions as well as it is a source of legitimacy to such decisions as part of democratic process. However, there are tremendous pressures from various actors such as government officials for cutting costs due to budgetary constraints, public managers for managing costs and quality, vendors for bargaining and deciding cost versus service quality measures, technical and line staff for administrating negotiations and producing services, and citizens for receiving services in exchange of price they pay in the form of taxes. This study examines the effects of citizens and forms of government on the service decisions regarding health and human services. Findings fail to support citizen's role but indicate a significant role of form of government, partisanship orientation, and taxes in making alternative service delivery choices.
\end{abstract}

Keywords: citizen participation, alternative service delivery, forms of government, health and human services, local government

\section{Introduction}

There has always been pressure on governments to provide more and better ways of production and delivery of services while reducing the associated costs. There are two general ways of production and delivery of public services; first one is through the in-house set ups and the second is through the alternative service delivery mechanisms. Alternative service delivery is possible in collaboration with private sector, nonprofit organizations and/or other governments through contracts. Depending on the nature of the service and other constraints, it is also possible to have a combination of these providers to provide a single service. In this context, scholars have examined public service decisions through various lenses such as using transaction cost approach in terms of costs and benefits for make or buy alternatives (Williamson, 1981); quality versus cost and influences of bureaucratic forces (Ferris and Graddy, 1991b; Cooper, 2003). This dynamic situation calls for a balance among all the actors who actively pressurize the process where public managers seek to manage within the budgetary constraints, vendors for abiding the terms of contracts and providing quality services within the set time, technical officials for administering negotiations, oversight, and searching affordable alternatives, and citizens demand for uninterrupted quality services in return for their taxes. This study examines the influence of citizens on the decisions regarding provision of public services made at the local government level. The hypothesis to be tested include important factors such as influence of citizens on evaluating alternatives, implementation stage, form of government and population that have a vital role in public service delivery decisions by using two data sets from International City/County Management Association (ICMA) and population data from Census Bureau survey.

This is an important study for local governments and public managers because it helps in understanding the importance of citizen's influence on alternative service decisions. Furthermore, this study contributes to the literature by empirically testing this influence on local governments' service delivery decisions and how these decisions are shaped by the population and form of local government. 


\section{Private Service Delivery}

For the past few decades the major focus of decisions for local governments is less on deciding what services to provide and more on how best to provide these services. The alternatives available for contracting out these services include private vendors, nonprofits, and other governments. For this reason the present study combines private for profit and private nonprofit organizations as categorized in the ICMA (2007) survey to use in the development of the dependent variable for analysis. Local governments are very sensitive to the changes in economic conditions and at the same time have to be attentive to the needs of its citizens. This makes it important for local governments and communities to find ways to adequately address the present problems and actively plan for any possible future situations.

However, the reliance on contracts has increased to such a large proportion in the total work of governmental services resulting in a diminished role as direct service providers (Kettl, 1993). This emphasis on contracting out of governmental services and functions has reached such a level that scholars now refer to governments as "hollow states" (Milward and Provan, 2000) and argue that governments are now reduced to entities that only look after the contracts. In this vein, Brown, Potoski and Slyke (2006) argue that the advocates of contracting come from the public sector economics inclinations while the critics of contracting are from more traditional public administration backgrounds. These critics posit that contracting undermines the "value" based equality of treatment to the public at large. The in house mechanisms offer strong accountability tools and equality of treatment (Kettle, 1993). Another reason for this may be due to uneven nature of investments made by governments in the contracting activities because of the internal and external threats to performance of contracts (Brown and Potoski, 2003a). Local government service contracting has its own shortcomings in the form of price gouging, incomplete information, and chances of opportunistic behavior. Scholars have found that the circumstances and other factors play an important role in the choice between direct and alternative service delivery such as laws, costs and constraints such as time, political pressure, and availability of vendors. Furthermore, the decision to buy or produce also depends on the nature of the service to be delivered (Clingermayer, Stream, and Feiock, 2008).

Contracting is more suitable for low risk services that are easier to measure and quality can be determined which Williamson (1981) refers to as asset specificity and service measurability. Asset specificity refers to any specific investments, hardware or resources required to produce a service that are not easily available or replaceable. Service measurability refers to the difficulties associated with the measurement of the outputs, this is important for determining of input resources required, monitoring and accountability purposes.

Lamothe, Lamothe and Feiock (2008) examined local government service delivery arrangements over time capturing the dynamic nature of the contracting process. They argue that past contractual arrangements tend to introduce elements of inertia and incrementalism thus making any fundamental changes in future contractual arrangements difficult for public managers. Similarly, scholars have argued about "contracting back in" which refers to the phenomenon where local governments develop in house capabilities to provide services that were contracted out (Warner and Hefetz, 2009). However, this argument overlooks the joint production mechanisms and the influence of previous contractual arrangements on future arrangement (Lamothe, Lamothe, and Feiock, 2004).

This paper begins with the theoretical argument for choices between in house and alternative delivery of public services. The next section describes citizens as stakeholders and explains their influence on the public service delivery choices. After that it examines the varied influences on such decisions with a focus on the form of government. Further, I develop a set of hypotheses based on the influence of these factors on private service delivery choices. In the next section I include methodology, variables description and data sets used for analysis. The findings, discussion of results and conclusions followed by the possible avenues for future research are part of the last section of the paper.

\section{Citizens as Stake Holders}

Citizens are at the center of any government activity related to public service decisions and they are best suited to identify social needs and evaluate the measures taken to fulfill those needs. Therefore, citizens as the recipients of public services have a major role in the make or buy decisions relating to public services as well as in the evaluation of feasibility of these services (Miller and Miller, 1991). However level of any such participation is determined by the initiatives undertaken to engage citizens in a meaningful way to enhance the quality of decisions and increase the efficiency of public organizations. Furthermore, under the principal agent theory citizens have the right to monitor the use of their tax dollars to select the best available option. Otherwise, there is the possibility that citizens might opt to vote with their feet Tiebout (1956) which also shows their 
influence on politicians and public processes. Wagenet and Pfeffer (2007) argue that any planning without input from citizens may result in unsuccessful management which is detrimental to the achievement of organizational goals.

In this regard, consumer associations and other governmental or non-governmental organizations may serve to represent the collective interest of citizens. This makes citizens as participants who may define, enable or constrain any business intentions such as in house or contracting out of public services (Crane, Matten, and Moon, 2004). Furthermore, citizens as stake holders not only participate in evaluation of options and monitoring but also influence the choices made through feedback for quality and quantity of services provided by their governments.

\section{Forms of Government}

ICMA categories local governments generally into five forms: mayor-council, council-manager, commission, town meeting, and representative town meeting. However the two most common forms of city government are Council-Manager and Mayor-Council. In a Mayor-Council government an elected mayor serves as the city's chief administrative officer and an elected council that forms the city's legislative body. On the other hand, in a typical council-manager form of government an elected council looks after the policy areas while a professional manager is appointed by the council for administration (Levin and Tadelis, 2010). Eventhough their areas of responsibility are different but in recent times these distinctions have somewhat blurred where council members involve in some operational issues and managers may take part in short term policy formulation (Svara, 1999). However, such interchange of roles demand for a balanced approach including the necessary give and take in the duties of both these roles (Zhang and Feiock, 2010).

Public services are provided by the local governments but such services may be delivered by the local government, or through contractual arrangements. The decision to provide a specific service is dependent on a number of factors but once the choice is made to provide a service the most important step is to select the service provider (Ferris and Graddy, 1991a). This selection is often heavily influenced by political and economic factors. If decision to work with private sector is based on the economic rationale there may be added advantage of further investments and job creation for the community (Feiock, 2002). Furthermore, as rational actors politicians would like to secure all advantages for reelection while managers would strive for opportunities that help in their promotion during the whole process as explained by Frant (1996) through what he calls high powered and low powered incentives in public sector. Scholars have also associated the inclinations of council manager governments to contract out the delivery of public services with professionalism, innovation and efficiency motives (Clingermayer and Feiock, 2001; Lubell, Feiock, and Ramirez, 2005).

Hence managers are actively involved throughout the contracting process and take most responsibility for the practical decisions for private service delivery choices. They also find themselves in the most delicate position in the process and bear the pressures form political bosses, vendors, citizens, and other public employees. From the point of view of the local government setup these managers become responsible for the outcomes of any such arrangements for the provision and delivery of public services.

\section{Project Description}

Contracting for public services including health and human services has been the attention of research by many scholars who have examined it through various lenses. Based on the examination of contracts for health and human services, Milward and Provan (2000) forward the argument of "hollow state." They observe that the system for the provision of health and human services has changed from hierarchical to a much complex combination of private, nonprofit, and government entities in which stability, effectiveness, risk and property rights play an influential role. Beinecke and DeFillippi (1999) argue that alternative service delivery mechanisms for health and human services are beneficial in terms of cost, flexibility, performance measurement and accountability. However, these services require a dynamic relationship between the contractors, managers and citizens due to complexity of health services. This would also require active participation by citizens and managers during the whole contracting process so that maximum benefits can be gained under certain environmental, organizational, and behavioral conditions (DeHoog, 1985). Similarly, Warner and Hefetz (2009) find an increasing trend of hospital services provided by for-profit or non-profit arrangements. They observed an identical trend for other associated areas such as training, and welfare services.

From the discussion so far, following hypotheses are forwarded:

Hypothesis 1: Citizens are more likely to have a positive influence on the evaluation and adoption decisions of local government service delivery choices for health and human services. 
Hypothesis 2: Council-Manager form of government is likely to have a positive influence on the decisions for service delivery choices for health and human services.

Hypothesis 3: Political partisanship of citizens is likely to influence positively on the implementation decisions of local government service delivery choices for health and human services.

\section{Methodology and Analysis}

\subsection{Dependent Variable}

The dependent variable for service delivery choice is calculated by adding the responses to the questions that ask if the service is provided by the jurisdiction at present through private for profit or private nonprofit for the items related to health and human services. Therefore, for the purpose of this analysis a service is coded 0 if provided through private arrangements and 1 if provided by the local government through in house service delivery arrangements. Health and human services in the ICMA (2007) survey have several items which are added together to form the dependent variable, detail of items is given in appendix B. The Cronbach's alpha for the cumulative health and human services dependent variable is 0.729 .

\subsection{Measuring Citizen Evaluation}

The evaluation of alternative service delivery choices by Citizens is measured by the response to the related question in the ICMA (2007) survey. This question asks about the role of citizens in evaluating the private service delivery choice, the responses are coded 1 for yes and 0 for no.

\subsection{Form of Government}

Form of government data is also available from ICMA (2006) survey. Public administration literature has discussed the significance of the forms of government in the study of local governments in a large number of studies. It is treated as a dichotomous variable for local governments with city manager type of arrangements. Therefore, data for form of government is arranged so that the local governments employing managerial form of set ups are coded 1 while all other are coded 0 for analysis.

\subsection{Population}

Population data is gathered from the Census Bureau survey and it is used as control variable to facilitate in the analysis. Population of a city/county gives a clear indication of the level of service required and also points to the burden on resources.

\subsection{Partisanship}

Political partisanship of citizens at local government level is based on the voting patterns in the 2004 US Presidential elections. The number of votes for Republican Party and Democrat Party candidates were compared and coded 1 if Republican Presidential candidate secured more votes than the competitor.

\section{Data Analysis}

The study area for this research is the local governments covered by the Profile of Local Government Service Delivery Choices survey conducted by ICMA in 2007.

According to ICMA, "surveys were mailed to the Chief Administrative Officers in municipalities with populations 10,000 and over, in counties with populations 25,000 and over, and to a random sample of one in eight municipalities from 2,500 to 9,999 in population and one in eight counties with populations from 2,500 to 24,999." This survey focused on local government's service delivery choices and for the purpose of this study data for population and the form of government are incorporated from Census Bureau survey and ICMA survey for Form of Government. Of the 6,095 municipalities and counties that received surveys, 1,599 responded $(26.2 \%)$ and the responses for specific health and human service are still less. This provided a usable sample size of 375 local governments for this study.

Addition of population and form of government data in the study helps to form a robust model. Taking into consideration the binary (categorical) nature of the dependent variable, this study uses logit analysis for estimating the likelihood of effects of citizen engagement and form of government on the choice of local government service delivery.

The descriptive statistics for the variables used to study the alternative service delivery choices in local governments are provided in Table 1: 
Table 1. Descriptive statistics

\begin{tabular}{lllll}
\hline & Mean & Standard Deviation & Minimum & Maximum \\
\cline { 2 - 5 } Citizen-evaluation & .066313 & .2491591 & 0 & 1 \\
Form of government & .3129973 & .4643295 & 0 & 1 \\
Partisanship & .7718833 & .4201759 & 0 & 1 \\
Poverty & 13.62918 & 6.608597 & 3.1 & 51.1 \\
Income & 19846.41 & 4149.226 & 9730 & 35927 \\
Tax & 3271.593 & 548.1072 & 2328 & 5260 \\
Population & 10.87858 & 1.287694 & 7.831617 & 14.86153 \\
Age & 37.57154 & 3.715648 & 23.9 & 50 \\
White & 84.25199 & 15.07444 & 19.1 & 99.5 \\
\hline
\end{tabular}

The logit is the natural logarithm of the odds that gives values from negative to positive infinity. Positive numbers less than 1 give negative logarithms where logarithm of 1 is 0 . Thus, a negative coefficient means that the odds ratio is less than 1 ; both indicate that the odds or probability of dependent variable decreases as this independent variable increases. On the other hand a positive logit coefficient means that odds ratio is greater than 1 , indicating that the odds or probability of dependent variable increases with the increase in the independent variable.

The likelihood to affect the choice for health and human services is modeled as a linear function of independent and control variables:

Logit (Health and human services) ${ }_{i}=\beta 0+\beta 1$ (citizen-evaluation) $+\beta 2$ (form of government) $+\beta 3$ (partisanship) $+\beta 4$ (poverty percentage $)+\beta 5$ (income-per capita) $+\beta 6$ (tax-per capita) $+\beta 7$ (log population) $+\beta 8$ (age) $+\beta 9$ (partisanship*age) $+\beta 10$ (white-percentage population)

The results obtained from the logistic regression are presented in Table 2:

Table 2. Logit results

\begin{tabular}{|c|c|c|c|c|}
\hline & Coefficient & Standard Error & $\mathbf{z}$ & $\mathbf{P}>|\mathbf{z}|$ \\
\hline Citizen- evaluation & -0.6287996 & 0.473217 & -1.33 & 0.184 \\
\hline Form of government & $-0.4317795^{*}$ & 0.255219 & -1.69 & 0.091 \\
\hline Partisanship & $5.085345^{*}$ & 3.04129 & 1.67 & 0.095 \\
\hline Poverty & -0.0160674 & 0.0296966 & -0.54 & 0.588 \\
\hline Income & -0.0000386 & .000041 & -0.094 & 0.347 \\
\hline Tax & $-0.0008271 * *$ & .000249 & -3.32 & 0.001 \\
\hline Population & $-0.3108827 * *$ & 0.108985 & -2.85 & 0.004 \\
\hline Age & 0.1103559 & 0.07196 & 1.53 & 0.125 \\
\hline Partisanship-Age & $-0.1345896^{*}$ & 0.0794837 & -1.69 & 0.090 \\
\hline White & 0.0068935 & 0.0103485 & 0.67 & 0.505 \\
\hline Constant & 2.798512 & 3.690838 & 0.76 & 0.448 \\
\hline Count $\mathrm{R}^{2}$ for the test: 0.659 & & $\mathrm{LR} \mathrm{Chi}^{2}: 50.56$ & & \\
\hline
\end{tabular}
significant at $90 \%$ confidence level

** $\quad$ significant at $95 \%$ confidence level 
The detailed results are included in Appendix A.

\section{Findings and Discussion}

The overall model is statistically significant with $\mathrm{LR} \mathrm{Chi}^{2}$ value 50.56 at 0.000 level. However, the model fails to find statistical support for the influence of citizen evaluation on health and human service delivery arrangement.

The result for form of government is statistically significant and indicates that managerial form of government would prefer to contract-out health and human services through alternative service delivery arrangements. The results of this study are in accordance with results from previous studies (Hefetz and Warner 2004; Lamothe et al., 2004).

Partisanship, in this study reflects that Republican oriented partisanship basis in local governments indicates some statistically significant chances of keeping the delivery of health and human services through in house mechanisms. This finding in not in line with the general assumption that such partisan orientation reflects preference for privatization and encourages business practices in government activities. However, choice to keep the services under in house systems may point towards the renewed interest in developing local government capacity and expertise by taking the "high road" for restructuring the local governments (Ballard and Warner, 2000; Warner, 2008). Warner and Ballard (2000) argue that "contracting back in" is a developing trend in local government service, where "high road" focuses on internal management strengths to gain efficiencies while "low road" the "contracting out" of services impose additional costs, also the in house operations have additional advantage of utilizing capacity and save resources (Ammons and Fleck, 2010).

Poverty, income, age, and white population do not have statistically significant influences. However, taxes and population show strong support for providing health and human services through alternative delivery methods. It seems that the in house production of these services increases the tax burden across the board and to take advantages of expertise and economies of scale alternate delivery methods are preferred. Similarly, the increase in population may add to the service burdens of already resource deprived local governments to find ways to cater to the needs of citizens as much as possible by using the systems and resources developed in other sectors.

Overall, this study finds that there are strong indications that city managers prefer that health and human services to be provided through alternative service delivery methods. Also, population and tax burdens would encourage using alternative service delivery methods. Therefore, the results of the study may guide local governments to determine priorities in the delivery of health and human services through community based planning and integration for social and economic benefits. However, care must be taken in the general application of these findings because decisions to contract are sensitive to other important factors that may vary on case to case basis. For example, specific use of non-profits, official turnover, or geographic segregation provide a new dimension of service contracting (Feiock and Jang, 2003). Local governments also need to develop capacity for the feasibility, implementation, and evaluation for dealing with any adverse situations such as underperforming contracts (Brown and Potoski, 2003b) through listening to citizen's voice in the contract process as well as developing professional managerial capacities.

To overcome the limitations of this study and develop a more generalizable model a separate survey may be conducted to gather additional data from local governments who did not responded to the Health and Human Services items in the ICMA survey. Also, the items in the Health and Human Services category may be studied by developing sub categories to facilitate in developing models for particular aspects such as child care or elderly services. This may help in focused analysis and generate results that are useful for stake holders in decisions regarding alternative service delivery.

\section{Conclusion}

Local governments are always keen to find cost effective methods to provide quality public services. In this regards private service delivery provides avenues for local governments to achieve this goal. Scholars have examined the contract process through different criteria including cost benefits, financial aspects, bureaucratic characteristics and cost versus quality (Williamson, 1981; Benton and Menzel, 1992). This study forwarded the work of earlier scholars by using different data sets and incorporating citizen's evaluation, form of government, partisanship, demographic characteristics and tax burden to examine the decisions for public service delivery choices.

Future work may include other demographic and financial factors such as city size, detailed community characteristics, financial data, and specific service characteristics. This may help local governments to improve management of public programs through understanding of the alternative service delivery choices for Health and 
Human Services.

\section{References}

Ammons, D. N., \& Fleck, T. A. (2010). Budget-balancing tactics in local government. UNC School of Government. Retrieved from http://sogpubs.unc.edu/electronicversions/pdfs/BudgetBalancing.pdf

Ballard, M. J., \& Warner, M. E. (2000). Taking the high road: Local government restructuring and the quest for quality. Power Tools for Fighting Privatization (pp. 6/1-6/53). American Federation of State, County and Municipal Employees: Washington DC. Retrieved from http://cms.mildredwarner.org/p/23

Beinecke, R. H., \& DeFillippi, R. (1999). The value of the relationship model of contracting in social services reprocurements and transitions: Lessons from Massachusetts. Public Productivity and Management Review, 22(4), 490-501. http://dx.doi.org/10.2307/3380932

Benton, J. E., \& Menzel, D. C. (1992). Contracting and franchising county services in Florida. Urban Affairs Review, 27(3), 436-456. http://dx.doi.org/10.1177/004208169202700307

Brown, T. L., \& Matthew, P. (2003a). Transaction costs and institutional explanations for government service production decisions. Journal of Public Administration Research and Theory, 13(4), 441-468. http://dx.doi.org/10.1093/jopart/mug030

Brown, T. L., \& Matthew, P. (2003b). Contract-management capacity in municipal and county governments. Public Administration Review, 63(2), 153-164. http://dx.doi.org/10.1111/1540-6210.00276

Brown, T. L., Potoski, M., \& Van Slyke, D. M. (2006). Managing public service contracts: Aligning values, institutions, and markets. Public Administration Review, 66(3), 323-331. http://dx.doi.org/10.1111/j.1540-6210.2006.00590.x

Clingermayer, J. C., \& Feiock, R. C. (2001). Institutional constraints and policy choice: An exploration of local governance. Suny Press.

Clingermayer, J. C., Feiock, R. C., \& Stream, C. (2003). Contracting and sector choice for the delivery of local health and human services. State and Local Government Review, 35(3), 150-161. http://dx.doi.org/10.1177/0160323X0303500301

Cooper, P. J. (2003). Governing by contract: Challenges and opportunities for public managers. Washington, DC: C.Q. Press.

Crane, A., Matten, D., \& Moon, J. (2004). Stakeholders as citizens? Rethinking rights, participation, and $\begin{array}{lllll}\text { democracy. Journal of } & \text { Business }\end{array}$ http://dx.doi.org/10.1023/B:BUSI.0000039403.96150.b6

DeHoog, R. H. (1985). Human services contracting: Environmental, behavioral, and organizational conditions. Administration and Society, 16(4), 427-454. http://dx.doi.org/10.1177/009539978501600403

Feiock, R. C. (2002). A quasi-market framework for local economic development competition. Journal of Urban Affairs, 24(2), 123-142. http://dx.doi.org/10.1111/1467-9906.00118

Feiock, R. C., \& Jang. H. S. (2003). The role of nonprofits in the delivery of local services. Paper presented at Public Management Research Association Conference, Georgetown Public Policy Institute, Washington, D.C., October 9-11.

Ferris, J., \& Graddy, E. (1986). Contracting out: For what? With whom?. Public Administration Review, 46(4), 332-344. http://dx.doi.org/10.2307/976307

Ferris, J., \& Graddy, E. (1991). Production costs, transaction costs, and local government contractor choice. Economic inquiry, 29(3), 541-554. http://dx.doi.org/10.1111/j.1465-7295.1991.tb00845.x

Frant, H. (1996). High-powered and low-powered incentives in the public sector. Journal of Public Administration Research and Theory, 6(3), 365-81. http://dx.doi.org/10.1093/oxfordjournals.jpart.a024317

Hefetz, A., \& Warner, M. E. (2004). Privatization and its reverse: Explaining the dynamics of the government contracting process. Journal of Public Administration Research and Theory, 14(2), 171-190. http://dx.doi.org/10.1093/jopart/muh012

Innes, J. E., \& Booher, D. E. (2004). Reframing public participation: strategies for the 21 st century. Planning Theory and Practice, 5(4), 419-436. http://dx.doi.org/10.1080/1464935042000293170

International City/County Management Association. (2007). Profile of local government service delivery choices, 
survey data. Washington, DC: International City/County Management Association.

Kettl, D. F. (1993). Sharing power: Public governance and private markets. Washington, DC: The Brookings Institution.

Lamothe, M., Lamothe, S., \& Feiock, R. C. (2007). Vertical Integration in Municipal Service Provision. Working Paper. Retrieved from http://myweb.fsu.edu/rfeiock/papers/Vertical_Integration.pdf

Lamothe, S., Lamothe, M., \& Feiock, R. C. (2008). Examining local government service delivery arrangements over time. Urban affairs review, 44(1), 27-56. http://dx.doi.org/10.1177/1078087408315801

Leip, D. (2005). Dave Leip's Atlas of U.S. Presidential Elections. Retrieved from http://uselectionatlas.org

Levin, J., \& Tadelis, S. (2010). Contracting for government services: Theory and evidence from U.S. cities. Journal of Industrial Economics, 58(3), 507-541. http://dx.doi.org/10.1111/j.1467-6451.2010.00430.x

Lubell, M., Feiock, R. C., \& Ramirez, E. (2005). Political institutions and conservation by local governments. Urban Affairs Review, 40(6), 706-729. http://dx.doi.org/10.1177/1078087404274137

Miller, T. I., \& Miller. M. A. (1991). Standards of excellence: U.S. residents' evaluations of local government services. Public Administration Review, 51(6), 503-14. http://dx.doi.org/10.2307/976601

Milward, B. C., \& Provan, K. G. (2000). Governing the hollow state. Journal of Public Administration Research and Theory, 10(2), 359-380. http://dx.doi.org/10.1093/oxfordjournals.jpart.a024273

Svara, J. H. (1999). The shifting boundary between elected officials and city managers in large council manager cities. Public Administration Review, 59(1), 44-53. http://dx.doi.org/10.2307/977478

Tiebout, C. M. (1956). A pure theory of local expenditures. The Journal of Political Economy, 64(5), 416-424. http://dx.doi.org/10.1086/257839

Wagenet, L., \& Pfeffer, M. J. (2007). Organizing citizen engagement for democratic environmental planning. Society and Natural Resources, 20(9), 801-813. http://dx.doi.org/10.1080/08941920701216578

Warner, M. E. (2008). Local government infrastructure - and the false promise of privatization. Book chapter. Retrieved from http://government.cce.cornell.edu/doc/pdf/WarnerCenturyBook.pdf

Warner, M. E., \& Hefetz, A. (2009). Trends in public and contracted government services: 2002-2007. Policy Brief, 80. Retrieved from http://web.extension.illinois.edu/lgien/pdf/events/2012-01-19_trends.pdf

Williamson, O. E. (1981). The economics of organization: The transaction cost approach. American Journal of Sociology, 87(3), 548-77. http://dx.doi.org/10.1086/227496

Zhang, Y., \& Feiock, R. C. (2010). City managers' policy leadership in council-manager cities. Journal of Public Administration Research and Theory, 20(2), 461-476. http://dx.doi.org/10.1093/jopart/mup015 


\section{Appendix A}

\begin{tabular}{|c|c|c|c|c|c|c|}
\hline \multirow{4}{*}{$\begin{array}{l}\text { Iteration 0: } \\
\text { Iteration 1: } \\
\text { Iteration 2: } \\
\text { Iteration 3: }\end{array}$} & \multicolumn{6}{|c|}{$\log$ likelihood $=-255.88227$} \\
\hline & \multicolumn{6}{|c|}{$\log$ likelihood $=-230.64241$} \\
\hline & \multicolumn{6}{|c|}{$\log$ likelihood $=-230.60292$} \\
\hline & \multicolumn{6}{|c|}{$\log$ likelihood $=-230.60292$} \\
\hline \multirow{4}{*}{\multicolumn{4}{|c|}{ Logistic regression }} & \multicolumn{2}{|c|}{ Number of obs } & 375 \\
\hline & & & & \multicolumn{2}{|c|}{ IR $\operatorname{chi2}(10)$} & 50.56 \\
\hline & & & & \multicolumn{2}{|c|}{ Prob $>$ chi2 } & 0.0000 \\
\hline & & & & \multicolumn{2}{|c|}{ Pseudo R2 } & 0.0988 \\
\hline hlth & Coef. & Std. Err. & 2 & $P>|z|$ & [95\% Conf. & Interval] \\
\hline q3e & -.6287996 & .473217 & -1.33 & 0.184 & -1.556288 & .2986887 \\
\hline fog & -.4317795 & .255219 & -1.69 & 0.091 & -.9319996 & .0684406 \\
\hline prtnsp & 5.085345 & 3.04129 & 1.67 & 0.095 & -.875474 & 11.04616 \\
\hline pctprty & -.0160674 & .0296966 & -0.54 & 0.588 & -.0742716 & .0421369 \\
\hline pcincm & -.0000386 & .000041 & -0.94 & 0.347 & -.000119 & .0000418 \\
\hline pettax & -.0008271 & .000249 & -3.32 & 0.001 & -.0013151 & -.0003391 \\
\hline lgpop & -.3108827 & .108985 & -2.85 & 0.004 & -.5244894 & -.0972759 \\
\hline age & .1103559 & .07196 & 1.53 & 0.125 & -.030683 & .2513949 \\
\hline prtnage & -.1345896 & .0794837 & -1.69 & 0.090 & -.2903749 & .0211957 \\
\hline pctwht & .0068935 & .0103485 & 0.67 & 0.505 & -.0133892 & .0271762 \\
\hline cons & 2.798512 & 3.690838 & 0.76 & 0.448 & -4.435398 & 10.03242 \\
\hline
\end{tabular}

- fitstat

Measures of Fit for logit of hlth

$\begin{array}{lrlr}\text { Log-Lik Intercept Only: } & -255.882 & \text { Log-Lik Full Model: } & -230.603 \\ \text { D(364): } & 461.206 & \text { LR(10): } & 50.559 \\ & & \text { Prob > LR: } & 0.000 \\ \text { McFadden's R2: } & 0.099 & \text { McFadden's Adj R2: } & 0.056 \\ \text { ML (Cox-Snell) R2: } & 0.126 & \text { Cragg-Vhler (Nagelkerke) R2: } & 0.169 \\ \text { Mckelvey \& Zavoina's R2: } & 0.169 & \text { Efron's R2: } & 0.129 \\ \text { Variance of Y*: } & 3.959 & \text { Variance of error: } & 3.290 \\ \text { Count R2: } & 0.659 & \text { Adj Count R2: } & 0.200 \\ \text { AIC: } & 1.289 & \text { AIC } & 483.206 \\ \text { BIC: } & -1696.195 & \text { BIC': } & 8.711 \\ \text { BIC used by Stata: } & 526.402 & \text { AIC used by Stata: } & 483.206\end{array}$




\section{Appendix B}

ICMA 2007: Items for Health \& Human Services

\begin{tabular}{ll}
\hline$\#$ & \multicolumn{1}{c}{ Item } \\
\hline 32 & Sanitary inspection \\
33 & Insect/rodent control \\
34 & Animal control \\
35 & Operation of animal shelters \\
36 & Operation of daycare facilities \\
37 & Child welfare programs \\
38 & Programs for the elderly \\
39 & Operation/management of hospitals \\
40 & Public health programs \\
41 & Drug and alcohol treatment programs \\
42 & Operation of mental health/mental retardation programs and facilities \\
43 & Prisons/jails \\
44 & Operation of homeless shelters \\
45 & Workforce development/job training programs \\
46 & Intake/eligibility determination for welfare programs \\
\hline
\end{tabular}

Cronbach's Alpha

alpha q32 q33 q34 q35 q36 q37 q38 q39 q40 q41 q42 q43 q44 q45 q46

Test scale $=$ mean (unstandardized items)

Average inter item covariance: $\quad .0121055$

Number of items in the scale:

Scale reliability coefficient: $\quad 0.7296$

\section{Copyrights}

Copyright for this article is retained by the author(s), with first publication rights granted to the journal.

This is an open-access article distributed under the terms and conditions of the Creative Commons Attribution license (http://creativecommons.org/licenses/by/4.0/). 